\title{
Article \\ Development of Solid Phase Extraction Method Based on Ion Imprinted Polymer for Determination of Cr(III) Ions by ETAAS in Waters
}

\author{
Laura Trzonkowska, Barbara Leśniewska * (D) and Beata Godlewska-Żyłkiewicz (D)
}

Citation: Trzonkowska, L.; Leśniewska, B.; GodlewskaŻyłkiewicz, B. Development of Solid Phase Extraction Method Based on Ion Imprinted Polymer for

Determination of $\mathrm{Cr}$ (III) Ions by ETAAS in Waters. Water 2022, 14, 529 https://doi.org/10.3390/w14040529

Academic Editor: Laura Bulgariu

Received: 8 January 2022

Accepted: 7 February 2022

Published: 10 February 2022

Publisher's Note: MDPI stays neutral with regard to jurisdictional claims in published maps and institutional affiliations.

Copyright: (C) 2022 by the authors. Licensee MDPI, Basel, Switzerland. This article is an open access article distributed under the terms and conditions of the Creative Commons Attribution (CC BY) license (https:// creativecommons.org/licenses/by/ $4.0 /$ )
Department of Analytical Chemistry, Faculty of Chemistry, University of Bialystok, Ciołkowskiego 1K, 15-245 Bialystok, Poland; laurita88@interia.eu (L.T.); bgodlew@uwb.edu.pl (B.G.-Ż.)

* Correspondence: blesniew@uwb.edu.pl; Tel.: +48-85-7388093

\begin{abstract}
In this work, a new solid phase extraction method for the determination of chromium species in water samples by electrothermal atomic absorption spectrometry was developed. For selective separation of $\mathrm{Cr}(\mathrm{III})$ ions under dynamic conditions, two ion imprinted polymers containing $\mathrm{Cr}$ (III)-1,10-phenanthroline complex (Cr(III)-phen) were prepared with the use of one (styrene, ST) or two (styrene and 4-vinylpyridine, ST-4VP) functional monomers. The physicochemical properties of those solid sorbents towards $\mathrm{Cr}$ (III) ions were studied and compared. It was found that $\mathrm{Cr}$ (III) ions were retained on the $\mathrm{Cr}$ (III)-phen-ST and $\mathrm{Cr}(\mathrm{III})$-phen-ST-4VP polymers with high efficiency and repeatability $(91.6 \%$ and $92.9 \%, \mathrm{RSD}<2 \%)$ from solutions at $\mathrm{pH} 4.5$. The quantitative recovery of the analyte $(91.7 \%$ and $93.9 \%$, RSD $<4 \%)$ was obtained with 0.1 mol/L EDTA solution. The introduction of $4 \mathrm{VP}$, an additional functional monomer, improved selectivity of the $\mathrm{Cr}$ (III)-phen-ST-4VP polymer towards $\mathrm{Cr}(\mathrm{III})$ ions in the presence of $\mathrm{Cu}(\mathrm{II}), \mathrm{Mn}$ (II) and $\mathrm{Fe}(\mathrm{III})$ ions, and slightly decreased the sorption capacity and stability of that polymer. The accuracy of procedures based on both polymeric sorbents was proved by analyzing the standard reference material of surface water SRM 1643e. The method using the $\mathrm{Cr}$ (III)-phen-ST polymer was applied for determining of $\mathrm{Cr}$ (III) ions in tap water and infusion of a green tea.
\end{abstract}

Keywords: Chromium(III); separation; SPE; ion imprinted polymer; water

\section{Introduction}

Chromium is commonly used for the production of steel and other alloys, bricks, dyes and pigments, leather tanning, electroplating and wood preserving [1]. It was reported that occupational exposure to trivalent chromium can lead to oxidative stress and DNA damage in tannery workers [2]. Due to extensive use in industrial processes, large quantities of Cr compounds are discharged into the environment and contaminate the air, soil, surface water and groundwater. Chromium occurs in the environment in two oxidation states, as $\mathrm{Cr}(\mathrm{III})$ and $\mathrm{Cr}(\mathrm{VI})$ compounds, which differ in terms of chemical behavior, biological activity and toxic effects [3]. Chromium(VI) has a mutagenic and carcinogenic effect on living organisms $[2,3]$. On the other hand, chromium(III) has been recommended for years as a trace element necessary for the proper functioning of organisms. However, recent studies indicate that chromium, currently, can only be considered as pharmacologically active and not as an essential element [4]. Despite this, some national authorities have left the adequate intake (AI) values of $\mathrm{Cr}$ in their Dietary Reference Values, e.g., $35 \mu \mathrm{g} / \mathrm{d}$ for men and $25 \mu \mathrm{g} / \mathrm{d}$ for women in USA, $70 \mu \mathrm{g} / \mathrm{d}$ for men and $55 \mu \mathrm{g} / \mathrm{d}$ for women in France and 30-100 $\mu \mathrm{g} / \mathrm{d}$ for adults in Germany [5]. $\mathrm{Cr}$ (III) is widely used in dietary supplements that either support weight loss or improve glucose metabolism in type 2 diabetes [6]. However, the safety of consuming chromium compounds in food is being disputed, as high dietary doses of $\mathrm{Cr}$ (III) can probably limit the absorption of iron and zinc ions, as well as affect calcium metabolism in bones. $\mathrm{Cr}(\mathrm{III})$, as a metalloestrogen, is also associated with 
induction of oxidative stress associated with the excessive production of reactive oxygen species which damage cell biomolecules [2]. It has been reported that exposure to $\mathrm{CrO}_{3}$ and $\mathrm{CrCl}_{3}$ induce genetic mutation in cultured in vitro yeast cells and cause DNA damage within yeast cells and human leukemic T cell lymphoblast (Jurkat cells). In addition, a significantly greater ability of $\mathrm{Cr}(\mathrm{III})$ to generate DNA damage than that of $\mathrm{Cr}(\mathrm{VI})$ was observed [7]. Due to the growing consumption of $\mathrm{Cr}(\mathrm{III})$ in the form of dietary supplements and doubts of its safety use, assessing the genotoxic risk of $\mathrm{Cr}$ (III) is especially important and requires further research [2].

In natural waters, the presence and concentration ratio of $\mathrm{Cr}(\mathrm{III})$ and $\mathrm{Cr}(\mathrm{VI})$ forms depend on the following: chemical and photochemical redox reactions; precipitation/ dissolution; adsorption/desorption or complexation processes, and chromium concentration, $\mathrm{pH}$ and redox potential [8]. Under environmental conditions, more mobile species of $\mathrm{Cr}(\mathrm{VI})$ can undergo redox transformation and form a labile and more stable species of $\mathrm{Cr}(\mathrm{III})$, which are predominant in water. These $\mathrm{Cr}$ (III) aqua/hydroxo complexes have tendency to be adsorbed on naturally occurring solid material, whereas organic complexes can be immobilized by macromolecular compounds, which leads to the accumulation of $\mathrm{Cr}(\mathrm{III})$ in bottom sediments [8,9]. Therefore, the contamination of surface waters with chromium, mainly in the form of $\mathrm{Cr}(\mathrm{III})$, has become a global problem. It was found that $\mathrm{Cr}(\mathrm{III})$ may have an adverse effect on freshwater fish [10], meaning its determination in the aquatic environment is important for assessing the risk to human health. According to the European Council Directive 98/83/EC, the maximum concentration of total chromium in drinking water intended for human consumption cannot exceed $50 \mu \mathrm{g} / \mathrm{L}$ [11].

The determination of chromium species in water samples requires reliable and accurate analytical procedures. Due to the high toxicity of $\mathrm{Cr}(\mathrm{VI})$, most researchers are focused on the development of analytical methods for its selective determination in various samples [12,13]. Additionally, selective determination of $\mathrm{Cr}(\mathrm{III})$ is relevant because of its recently reported adverse effects on living organisms [2,10]. Despite recent advances in instrumental analysis, direct determination of chromium species, especially $\mathrm{Cr}(\mathrm{III})$, in environmental water samples is still difficult. This is due to the insufficient sensitivity of instrumental techniques and low concentrations of analytes in complex matrices, which can be often a source of interference during measurements. Therefore, special sample preparation methods that allow for the separation/preconcentration of various forms of chromium and for the removal of interfering substances are needed [14,15]. In recent years, solid phase extraction (SPE) has become one of the most popular techniques for the separation of chromium species, as it can be easily coupled with electrothermal atomic absorption spectrometry (ETAAS), inductively coupled plasma mass spectrometry (ICPMS) or inductively coupled plasma optical emission spectrometry (ICP-OES). Although commercially available materials are often used as solid sorbents, there has been an increasing interest in recent years to design special, new materials that are characterized by high selectivity for a given analyte, e.g., functionalized graphene and carbon nanotubes [16], nanocomposites [17,18], nanoparticles [15,19] or ion imprinted polymers [20-33].

Ion imprinted polymers (IIP) are prepared based on the concept of molecular imprinting, a modern method of synthesizing sorbents with desired properties [20-22]. IIP synthesis consists of immobilizing the matrix molecule, i.e., a complex of a metal ion with an appropriate ligand, in the polymer structure through a copolymerization reaction with functional and cross-linking monomers. The physicochemical properties of IIPs, their binding properties and their ability of selective recognition largely depend on both the specific interactions of the ligand with metal ions and the reagents used in the polymerization process. The advantages of IIPs are their specific affinity for a given ion, their stability and reusability, and their relative ease and low cost of preparation.

A review of the literature has shown that $\mathrm{Cr}(\mathrm{III})$ - ion imprinted polymers were prepared using $\mathrm{Cr}$ (III) complexes with 2-methacryloylamidohistidine (MAH) [23], nicotinic acid [24], 8-hydroxyquinoline [25], 1,5-diphenylcarbazide [26] and ammonium pyrrolidinedithiocarbamate [27] as templates. The polymeric structure was mainly formed by the 
cross-linking of methacrylic acid [26], acrylamide [24,27] with ethylene glycol dimethacrylate [24,27] or divinylbenzene [25]. The sorption properties of the prepared IIPs were tested in model solutions $[23,29]$, and a few of them were used for the analysis of chromium species in various environmental water samples $[23-25,27,28,30,33]$ [(Table 1$)$.

Table 1. Solid phase extraction methods with the use of ion imprinted polymers for determination of $\mathrm{Cr}(\mathrm{III})$ in aqueous samples.

\begin{tabular}{|c|c|c|c|c|c|c|c|c|c|c|c|}
\hline \multirow{2}{*}{ Analyte } & \multirow{2}{*}{$\begin{array}{c}\text { IIP as } \\
\text { SPE } \\
\text { Sorbent }\end{array}$} & \multirow[b]{2}{*}{$\underset{\mathbf{a}}{\text { Stability }}$} & \multicolumn{2}{|c|}{ Selectivity } & \multicolumn{3}{|c|}{ Separation Conditions } & \multirow{2}{*}{$\begin{array}{l}\text { LOD b } \\
\text { (Detection } \\
\text { Technique) }\end{array}$} & \multirow{2}{*}{$\begin{array}{l}\text { Analyzed } \\
\text { Samples }\end{array}$} & \multirow{2}{*}{$\begin{array}{c}\text { Recovery, } \\
\%\end{array}$} & \multirow[b]{2}{*}{ Ref. } \\
\hline & & & Interf. & $\alpha$ & $\mathrm{pH}$ & $\begin{array}{c}\text { Time or } \\
\text { Flow Rate }\end{array}$ & Elution & & & & \\
\hline \multicolumn{12}{|c|}{ Static Separation Mode } \\
\hline $\mathrm{Cr}(\mathrm{III})$ & $\begin{array}{c}\text { Cr(III)- } \\
\text { GA- } \\
\text { MMA- } \\
\text { EGDMA }\end{array}$ & & $\begin{array}{l}\mathrm{Fe}(\mathrm{III}) \\
\mathrm{Ag}(\mathrm{I})\end{array}$ & $\begin{array}{l}4.1 \\
4.7\end{array}$ & 5 & $120 \mathrm{~min}$ & $\begin{array}{c}0.1 \mathrm{~mol} / \mathrm{L} \\
\mathrm{HNO}_{3}\end{array}$ & FAAS & lake water & $110-120$ & [28] \\
\hline $\begin{array}{l}\mathrm{Cr}(\mathrm{III}) \\
\mathrm{Cr}(\mathrm{VI})\end{array}$ & $\begin{array}{l}\mathrm{Cr}(\mathrm{III})- \\
\text { MAH- } \\
\text { EGDMA } \\
{ }^{\mathrm{C}} \mathrm{Cl}-\end{array}$ & 5 & $\begin{array}{l}\mathrm{Co}(\mathrm{II}) \\
\mathrm{Ni}(\mathrm{II}) \\
\mathrm{Cr}(\mathrm{VI})\end{array}$ & $\begin{array}{l}3.8 \\
4.4 \\
3.2\end{array}$ & 6 & $30 \mathrm{~min}$ & $\begin{array}{l}0.1 \mathrm{~mol} / \mathrm{L} \\
\text { succinic } \\
\text { acid }\end{array}$ & $\begin{array}{l}1.2 \mathrm{ng} / \mathrm{mL} \\
\text { (FAAS) }\end{array}$ & $\begin{array}{l}\text { model } \\
\text { solutions }\end{array}$ & & [23] \\
\hline $\mathrm{Cr}(\mathrm{III})$ & $\begin{array}{c}\text { SBA-15: } \\
\text { Cr(III)- } \\
\text { DZ- } \\
\text { MAA- } \\
\text { EGDMA }\end{array}$ & 10 & & & 6 & d 6 min & $\underset{\mathrm{HCl}}{2 \mathrm{~mol} / \mathrm{L}}$ & $\begin{array}{l}0.06 \mathrm{ng} / \mathrm{mL} \\
\quad(\text { FAAS) }\end{array}$ & $\begin{array}{l}\text { tap, river } \\
\text { and spring } \\
\text { water }\end{array}$ & $96-105$ & [33] \\
\hline \multicolumn{12}{|c|}{ Dynamic Separation Mode } \\
\hline $\begin{array}{c}\mathrm{Cr}(\mathrm{VI}), \\
\mathrm{Cr}(\mathrm{III})+ \\
\mathrm{Cr}(\mathrm{VI})\end{array}$ & $\begin{array}{l}{ }^{\mathrm{c}} \mathrm{SiO}_{2}: \\
\mathrm{Cr}(\mathrm{III})- \\
\text { AAPTS }\end{array}$ & 100 & Mn(II) & 768 & $\begin{array}{l}2 \\
7\end{array}$ & $2 \mathrm{~mL} / \mathrm{min}$ & $\begin{array}{c}1 \mathrm{~mol} / \mathrm{L} \\
\mathrm{HNO}_{3}\end{array}$ & $\begin{array}{c}0.008 \mathrm{ng} / \mathrm{mL} \\
0.004 \mathrm{ng} / \mathrm{mL} \\
\text { (ICP-MS) }\end{array}$ & $\begin{array}{l}\text { lake, tap and } \\
\text { well water }\end{array}$ & $99-100$ & [30] \\
\hline $\mathrm{Cr}(\mathrm{III})$ & $\begin{array}{c}\text { Cr(III)- } \\
\text { nic-AA- } \\
\text { EGDMA }\end{array}$ & 100 & $\begin{array}{l}\mathrm{Cu}(\mathrm{II}) \\
\mathrm{Mn}(\mathrm{II}) \\
\mathrm{Ni}(\mathrm{II}) \\
\mathrm{Co}(\mathrm{II})\end{array}$ & $\begin{array}{l}3.1 \\
3.7 \\
2.5 \\
3.1\end{array}$ & 9 & $\begin{array}{c}0.6 \\
\mathrm{~mL} / \mathrm{min}\end{array}$ & $\begin{array}{c}4 \mathrm{~mol} / \mathrm{L} \\
\mathrm{CH}_{3} \mathrm{COOH}\end{array}$ & $\begin{array}{c}80 \mathrm{ng} / \mathrm{mL} \\
\text { (FAAS) }\end{array}$ & $\begin{array}{c}\text { wastewater, } \\
\text { RES } 10.2\end{array}$ & $93-109$ & [24] \\
\hline $\mathrm{Cr}(\mathrm{III})$ & $\begin{array}{l}\text { Cr(III)- } \\
\text { 8HQ-ST- } \\
\text { DVB }\end{array}$ & 170 & $\begin{array}{l}\mathrm{Cu}(\mathrm{II}) \\
\mathrm{Mg}(\mathrm{II}) \\
\mathrm{Ca}(\mathrm{II})\end{array}$ & $\begin{array}{c}44.8 \\
1444 \\
147\end{array}$ & 9 & $1 \mathrm{~mL} / \mathrm{min}$ & $\underset{\mathrm{HNO}_{3}}{0.1 \mathrm{~mol} / \mathrm{L}}$ & $\begin{array}{l}2.1 \mathrm{ng} / \mathrm{mL} \\
\text { (FAAS) }\end{array}$ & $\begin{array}{c}\text { wastewater, } \\
\text { RES } 10.2\end{array}$ & $90-107$ & [25] \\
\hline $\mathrm{Cr}(\mathrm{III})$ & $\begin{array}{c}\text { Cr(III)- } \\
\text { PDC- } \\
\text { AA- } \\
\text { EGDMA }\end{array}$ & 200 & - & - & 4 & $1 \mathrm{~mL} / \mathrm{min}$ & $\begin{array}{c}0.2 \mathrm{~mol} / \mathrm{L} \\
\mathrm{HNO}_{3}\end{array}$ & $\begin{array}{l}0.018 \mathrm{ng} / \mathrm{mL} \\
\text { (ETAAS) }\end{array}$ & $\begin{array}{c}\text { surface } \\
\text { water, } \\
\text { wastewater }\end{array}$ & $90-100$ & [27] \\
\hline $\mathrm{Cr}(\mathrm{III})$ & $\begin{array}{c}\text { Cr(III)- } \\
\text { phen-ST }\end{array}$ & 107 & $\begin{array}{l}\mathrm{Cu}(\mathrm{II}) \\
\mathrm{Mn}(\mathrm{II}) \\
\mathrm{Fe}(\mathrm{III})\end{array}$ & $\begin{array}{l}16.7 \\
4.4 \\
9.6\end{array}$ & 4.5 & $1 \mathrm{~mL} / \mathrm{min}$ & $\begin{array}{c}0.1 \mathrm{~mol} / \mathrm{L} \\
\text { EDTA }\end{array}$ & $\begin{array}{l}0.018 \mathrm{ng} / \mathrm{mL} \\
\text { (ETAAS) }\end{array}$ & $\begin{array}{c}\text { surface } \\
\text { water SRM } \\
1643 \mathrm{e}, \\
\text { tap water, } \\
\text { tea infusion }\end{array}$ & $93-94$ & $\begin{array}{l}\text { This } \\
\text { work }\end{array}$ \\
\hline
\end{tabular}

a —stability of IIPs expressed as a number of sorption/desorption cycles, ${ }^{b}$ - LOD values after taking into account preconcentration factor of analyte on used sorbent, ${ }^{c}$ - surface imprinting on $\mathrm{SiO}_{2}$ - activated silica or Cl-SBA-15mesoporous silica modified with $\mathrm{Cl}^{-}, \mathrm{d}$ - dispersive solid phase extraction DSPE. AAPTS-3-(2-aminoethylamino) propyltrimethoxysilane, DZ-dithizone, MAA—-methacrylic acid, EGDMA — ethylene glycol dimethacrylate, MAH-2-methacryloylamidohistidine, nic - nicotinic acid, AA — acrylamide, 8HQ-8-hydroxyquinoline, STstyrene, DVB — divinylbenzene, PDC—pyrrolidinedithiocarbamate, phen-1,10-phenanthroline; LOD—limit of detection.

The prepared $\mathrm{Cr}(\mathrm{III})$-IIPs were used, mostly in a static mode, as solid sorbents in SPE due to the slow kinetics of analyte sorption and desorption process [23,29,31-33]. For example, sorption of $\mathrm{Cr}$ (III) from a solution of $\mathrm{pH} 6$ on the $\mathrm{Cr}$ (III)-MAH-EGDMA polymer occurred within $30 \mathrm{~min}$, whereas its desorption with $0.1 \mathrm{~mol} / \mathrm{L}$ succinic acid lasted $2 \mathrm{~h}$ [23]. The Cr(III)-IIPs, characterized by faster sorption kinetics, were applied in a dynamic mode [24-27], which allowed for the minimization of sample/reagent consumption and waste production. This reduced the risk of sample contamination as well as increased the sampling frequency [25]. Most of the described $\mathrm{Cr}(\mathrm{III})$-IIPs showed good selectivity towards $\mathrm{Cr}(\mathrm{III})$ ions in the presence of foreign ions as well as $\mathrm{Cr}(\mathrm{VI})$ ions. This, therefore, allowed for their use in the speciation analysis of chromium in wastewater $[24,25,31,32]$ and surface water samples [27,28,30,33]. However, the Cr(III)-MAH-EGDMA polymer [23] and silica imprinted with $\mathrm{Cr}(\mathrm{III})-\mathrm{AAPTS}$ [30], which had been synthesized in the presence of $\mathrm{Cr}(\mathrm{III})$ complexes, simultaneously retained both forms of chromium. As the successful 
separation of chromium species strongly depends on the properties of the sorbent used, research on the development of new selective and efficient sorbents is still needed.

The aim of this work was to develop a new dynamic SPE procedure for selective separation and determination of $\mathrm{Cr}$ (III) ions in water samples. We paid special attention to the design and preparation of solid sorbents characterized by good sorption properties including high efficiency and fast kinetics of the sorption and desorption process of the analyte, and versatile in practice and application. Based on our previous experience [34], we have prepared two ion imprinted polymers based on the $\mathrm{Cr}(\mathrm{III})-1,10-$ phenanthroline complex, containing aromatic rings that can be easily arranged in the polymer matrix. For the synthesis of both IIPs, neutral functional monomer-styrene, aprotic solventacetonitrile, divinylbenzene as a cross-linking monomer and AIBN as an initiator were used in bulk polymerization. This resulted in the first polymer, later referred to as $\mathrm{Cr}$ (III)phen-ST. For the second polymer obtained, referred to as Cr(III)-phen-ST-4VP, an additional functional monomer of 4-vinylpyridine (4VP) was applied. The physicochemical properties of both solid sorbents were evaluated and compared. The ability of these IIPs to separate and determine $\mathrm{Cr}(\mathrm{III})$ from water samples was assessed.

\section{Materials and Methods}

\subsection{Instrumentation}

For the determination of chromium, an atomic absorption spectrometer with electrothermal atomization and Zeeman background correction system Solaar M6 (Thermo Electron Corporation, Cambridge, UK) was used. The measurements of chromium were performed at wavelength $\lambda=357.9 \mathrm{~nm}$ with a $0.5 \mathrm{~nm}$ spectral bandpass using a chromium hollow cathode lamp (Photron, Narre Warren, Australia) operating at a $5.4 \mathrm{~mA}$ current. Integrated absorbances were measured using standard pyrolytically coated graphite tubes with the use of the following optimized time/temperature furnace program: drying at $110{ }^{\circ} \mathrm{C}$ for $20 \mathrm{~s}$, ashing at $1200^{\circ} \mathrm{C}$ for $8 \mathrm{~s}$, and atomization at $2600^{\circ} \mathrm{C}$ for $3 \mathrm{~s}$. Sample aliquots of $10 \mu \mathrm{L}$ volumes were dispensed from autosampler cups into the graphite furnace.

The FT-IR absorption spectra of polymers $\left(4000-500 \mathrm{~cm}^{-1}\right)$ in $\mathrm{KBr}$ were recorded using the Nicolet FT-IR 6700 spectrometer (Thermo Scientific, Newington, CT, USA). Surface areas of the polymers were measured using the surface area analyzer Gemini VII 2390 (Micrometrics, Norcross, GA, USA). Nitrogen sorption analysis was carried out using approximately $0.3 \mathrm{~g}$ portions of polymers degassed for $24 \mathrm{~h}$ at $80^{\circ} \mathrm{C}$. A scanning electron microscope SEM Inspect (FEI, Hillsboro, OR, USA) was used to study the morphology of polymer particles.

A solid phase extraction (SPE) system consisting of laboratory made glass columns (i.d. $3.15 \mathrm{~mm}$ ) filled with $0.1 \mathrm{~g}$ of the polymer, PTFE tubing of i.d. $0.8 \mathrm{~mm}$ and a peristaltic pump Minipuls 3 (Gilson, Villiers-le Bel, France) was used. The two ends of the columns were blocked with PTFE membranes.

For $\mathrm{pH}$ measurements, an inoLab pH Level 1 (WTW, Weiheim, Germany) $\mathrm{pH}$ meter equipped with an electrode SenTix 21 (WTW, Weiheim, Germany) was used.

\subsection{Reagents and Materials}

A stock solution $(20 \mathrm{mg} / \mathrm{mL})$ of $\mathrm{Cr}(\mathrm{III})$ as $\mathrm{CrCl}_{3}$ was prepared from Titrisol solution (Merck, Darmstadt, Germany). A stock solution $\left(1.001 \mathrm{mg} / \mathrm{mL}\right.$ ) of $\mathrm{Cr}(\mathrm{VI})$ as $\mathrm{K}_{2} \mathrm{Cr}_{2} \mathrm{O}_{7}$ (Sigma Aldrich, Steinheim, Germany) was used. Working standard solutions of chromium were prepared daily by diluting the stock solutions. Sodium hydroxide (p.a.) supplied by POCh (Gliwice, Poland) was used to adjust the $\mathrm{pH}$ of the samples and standards. Acetic acid ( $80 \%$, POCh, Gliwice, Poland) and ethylenediaminetetraacetic acid (EDTA) (POCh, Gliwice, Poland) were used as desorption agents. 1, 10-phenanthroline (phen), supplied by Sigma Aldrich (Steinheim, Germany), was used to prepare the Cr(III)-1,10-phenanthroline complex. Nitric acid (69.5\%, Trace Select, Fluka, Seelze, Germany) and hydrochloric acid (37\%, fuming, Trace Select, Fluka, Seelze, Germany) were used for digestion of the samples. Styrene (ST, 99\%, Merck, Darmstadt, Germany), 4-vinylpyridine (4VP, Sigma Aldrich, 
Steinheim, Germany), divinylbenzene (DVB, 80\%, mixture of isomers, Merck, Darmstadt, Germany), 2, 2'-azobisisobutyronitrile (AIBN, Fluka, Steinheim, Germany) and acetonitrile (Sigma Aldrich, Steinheim, Germany) were used for the synthesis of the ion-imprinted polymers. High-purity argon was used to de-aerate the solutions. For interference studies, solutions of copper(II) nitrate(V), manganese(II) nitrate(V) and iron(III) nitrate(V) (all supplied by Fluka, Steinheim, Germany) were used. Deionized water with $18.2 \mathrm{M} \Omega / \mathrm{cm}$ conductivity obtained from the Milli-Q water purification system (Millipore, Burlington, VT, USA) was used to prepare all of the solutions.

Standard reference material of surface water SRM 1643e (NIST, Gaithersburg, MD, USA) was used for accuracy control.

\subsection{Preparation of Ion Imprinted Polymers}

The IIPs were prepared in two steps. First, the binary complex of $\mathrm{Cr}(\mathrm{III})$ with 1,10phenanthroline (template) was formed. Then, the copolymerization of this complex was performed with suitable reagents using the bulk method. The complex of cis-dichloridobis $(1$, 10-phenanthroline)chromium(III) chloride $\left(\mathrm{Cr}(\mathrm{III}) \mathrm{Cl}_{2}(\text { phen })_{2}{ }^{+} \mathrm{Cl}^{-}\right)$, designated here as $\mathrm{Cr}$ (III)-phen, was prepared according to the procedure described in the work of Gao [35]. A $\mathrm{Cr}$ (III)-phen complex, containing $0.002 \mathrm{~g}$ (0.04 mmol) of $\mathrm{Cr}$ (III) was used for the synthesis of the IIPs. The Cr(III)-phen-ST polymer was prepared using styrene $(2.3 \mathrm{~mL}, 20 \mathrm{mmol})$, divinylbenzene $(11.2 \mathrm{~mL}, 80 \mathrm{mmol}), 2$, 2' -azobisisobutyronitrile $(0.050 \mathrm{~g})$ and acetonitrile (4 mL), whereas for the Cr(III)-phen-ST-4VP polymer, an addition of 4VP $(1.1 \mathrm{~mL}, 10 \mathrm{mmol})$ was included. In summary, all reagents were mixed in glass polymerization ampoules and purged for $10 \mathrm{~min}$ with argon. Next, they were left for $16 \mathrm{~h}$ at $80{ }^{\circ} \mathrm{C}$. Monolithic blocks of polymers were crushed and washed with dichloromethane, and then dried and sieved. Control polymers (CP) were synthesized in a similar way but without $\mathrm{Cr}(\mathrm{III})$ ions. The schematic illustration of bulk polymer preparation is presented in Figure 1. The efficiency of $\mathrm{Cr}$ (III) imprinting in the polymeric structure was evaluated as the ratio of the $\mathrm{Cr}$ content in IIPs determined after digestion of the polymer in a microwave oven $(0.1 \mathrm{~g} \mathrm{IIP}+5 \mathrm{~mL}$ of $\mathrm{HNO}_{3}+1 \mathrm{~mL}$ of $\mathrm{HCl}$ ) to the initial mass of $\mathrm{Cr}(\mathrm{III})$ used for polymers' synthesis.

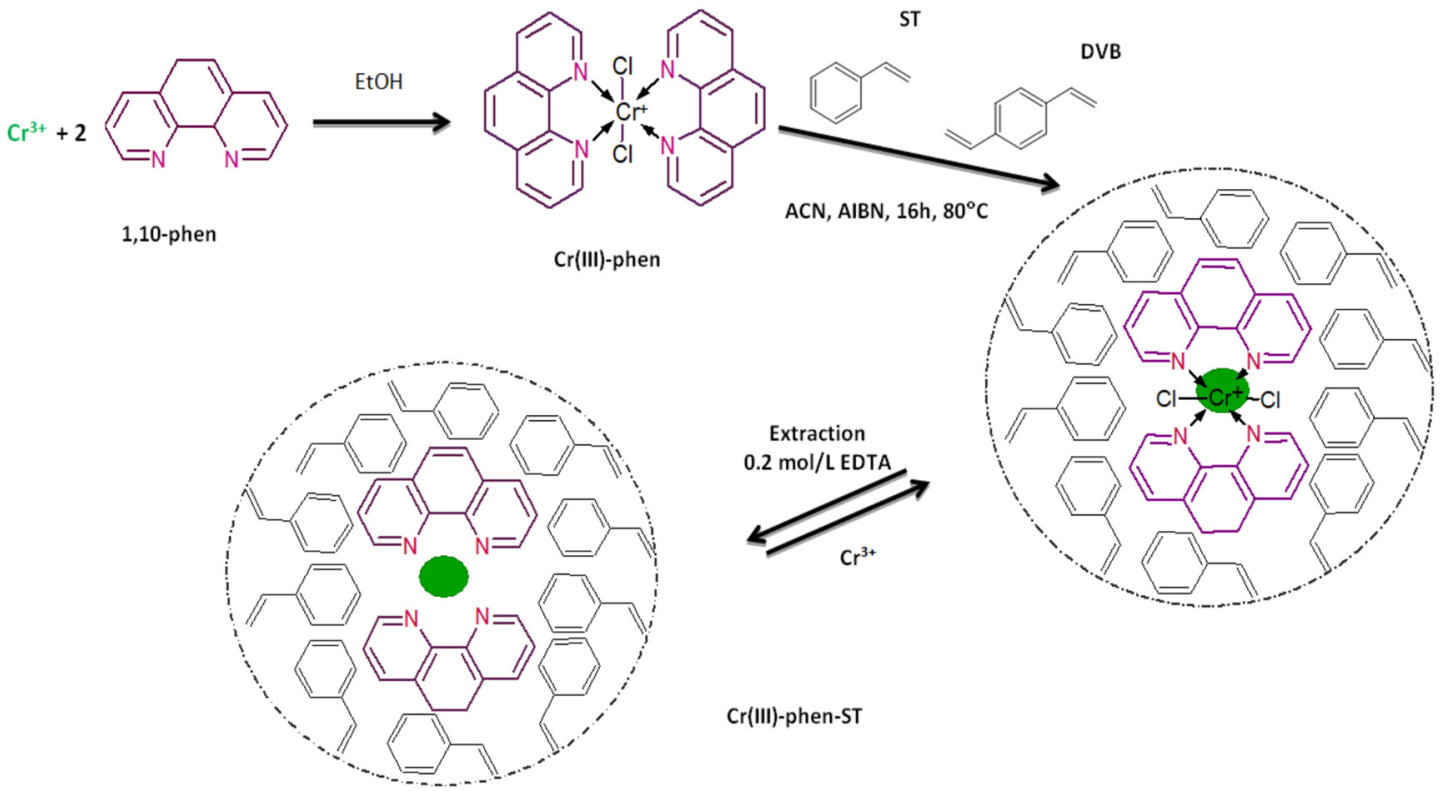

Figure 1. Schematic illustration of the imprinting process for preparation of the Cr(III)-phen-ST polymer by bulk polymerization.

The imprinted $\mathrm{Cr}(\mathrm{III})$ ions were leached from IIPs by passing $100 \mathrm{~mL}$ of $0.5 \mathrm{~mol} / \mathrm{L}$ $\mathrm{CH}_{3} \mathrm{COOH}$ and $100 \mathrm{~mL}$ of $0.2 \mathrm{~mol} / \mathrm{L}$ EDTA solutions through column filled with portions of the polymers $(0.5 \mathrm{~g})$ at a flow rate of $0.5 \mathrm{~mL} / \mathrm{min}$. The total amount of removed $\mathrm{Cr}(\mathrm{III})$ 
ions was evaluated by analyzing effluents from the IIPs. The efficiency of $\mathrm{Cr}$ (III) ions removal was calculated as the ratio of the total amount of leached $\mathrm{Cr}$ (III) ions to the amount of $\mathrm{Cr}$ imprinted in IIPs. In the final step, the polymers were rinsed with deionized water and dried at room temperature. A fraction 120-200 $\mu \mathrm{m}$ in diameter was used as a column filling.

The FT-IR spectra of the Cr(III)-phen-ST and the Cr(III)-phen-ST-4VP polymers (Figure S1) were registered and the following characteristic bands were observed: $-v(=\mathrm{C}-\mathrm{H})$ band at $3100-2849 \mathrm{~cm}^{-1},-v(-\mathrm{C}=\mathrm{C})$ band at $1600-1510 \mathrm{~cm}^{-1},-v(-\mathrm{C}-\mathrm{H})$ band at $1487-1446 \mathrm{~cm}^{-1}$ derived from the polymer matrix, $-v(-\mathrm{C}=\mathrm{N})$ band at $1635-1629 \mathrm{~cm}^{-1}$ and $-v(-\mathrm{C}-\mathrm{N})$ band at $1350-1150 \mathrm{~cm}^{-1}$ from $\mathrm{Cr}$ (III)-phen complex. In the spectrum of the Cr(III)-phen-ST-4VP polymer, the last two characteristic bands have a higher intensity as they can also originate from 4-vinylpyridine groups. The CPs have similar FT-IR spectra as the IIPs, thus indicating a similarity in their backbone structure. Some differences in the fingerprint region were observed.

\subsection{Procedures}

For $\mathrm{Cr}(\mathrm{III})$ adsorption, IIPs were conditioned by passing $1 \mathrm{~mL}$ of deionized water through glass columns packed with $0.1 \mathrm{~g}$ of the sorbents at a flow rate of $1 \mathrm{~mL} / \mathrm{min}$. For retention of the analyte, either the $\mathrm{Cr}$ (III) standards or sample solutions were adjusted to $\mathrm{pH} 4.5$ with $\mathrm{NaOH}$ solution and then were passed through the columns at a flow rate of $1 \mathrm{~mL} / \mathrm{min}$. In order to remove $\mathrm{Cr}(\mathrm{VI})$ ions and retained matrix components, the columns were rinsed with $2 \mathrm{~mL}$ of deionized water before the elution step. Elution of $\mathrm{Cr}$ (III) ions was performed with $1 \mathrm{~mL}$ of $0.1 \mathrm{~mol} / \mathrm{L}$ EDTA at a flow rate of $1 \mathrm{~mL} / \mathrm{min}$. The concentration of chromium in all solutions was determined using the ETAAS technique. All results are based on at least three parallel replications.

The retention efficiency was calculated as the ratio of the difference between the initial mass of $\mathrm{Cr}$ (III) in the solution loaded on the column and the mass of $\mathrm{Cr}$ (III) in the effluent, derived from the calibration graph, to the initial mass of $\mathrm{Cr}$ (III) in the solution loaded on the column. The recovery of $\mathrm{Cr}$ (III) was calculated as the ratio of analyte mass in the eluate to the initial mass of $\mathrm{Cr}$ (III) in the loaded solution. The concentration of $\mathrm{Cr}$ (III) in the eluate was calculated from the calibration graph obtained after separation of $\mathrm{Cr}$ (III) on the IIPs column by developed procedure.

In order to study the selectivity of IIPs towards $\mathrm{Cr}$ (III) ions in the presence of $\mathrm{Cu}(\mathrm{II})$, $\mathrm{Mn}(\mathrm{II})$ and $\mathrm{Fe}$ (III) ions, solutions containing equivalent amounts of $\mathrm{Cr}$ (III) and competitive metal (Me) ions $(10 \mathrm{ng} / \mathrm{mL})$ were passed through columns filled with IIPs. Then, the columns were rinsed with $2 \mathrm{~mL}$ of water and $\mathrm{Cr}(\mathrm{III})$ was eluted with $1 \mathrm{~mL}$ of a $0.1 \mathrm{~mol} \mathrm{~L}^{-1}$ EDTA solution. The concentrations of $\mathrm{Cr}$ (III) and other metal ions were measured in both the column effluent and the eluate. The distribution coefficient (D), selectivity coefficient $(\alpha)$ and relative selectivity coefficient $\left(\alpha^{\prime}\right)$ were calculated according to the following equations:

$$
\begin{gathered}
\mathrm{D}=\frac{\left(\mathrm{C}_{0}-\mathrm{C}_{\mathrm{f}}\right)}{\mathrm{C}_{\mathrm{f}}} \frac{\mathrm{V}}{\mathrm{m}} \\
\propto=\frac{\mathrm{D}_{\mathrm{Cr}(\mathrm{III})}}{\mathrm{D}_{\mathrm{Me}}} \\
\alpha^{\prime}=\frac{\propto_{\mathrm{IIP}}}{\propto_{\mathrm{CP}}}
\end{gathered}
$$

where $\mathrm{C}_{0}$ and $\mathrm{C}_{\mathrm{f}}$ are the initial and final concentrations of $\mathrm{Cr}(\mathrm{III})$ or competitive Me ions in the solution, [ng/mL, V-volume of the solution, $\mathrm{mL}$, and $\mathrm{m}$-mass of sorbent, $\mathrm{g}$.

The sorption capacity of the IIPs was determined by passing an aqueous $\mathrm{Cr}$ (III) solution $(10 \mathrm{ng} / \mathrm{mL})$ through columns packed with $0.1 \mathrm{~g}$ of sorbents and quantifying the content of chromium in each of the $0.3 \mathrm{~mL}$ effluent fractions using ETAAS. The experiment was completed when the efficiency of the $\mathrm{Cr}$ (III) retention decreased by $20 \%$. 


\subsection{Sample Preparation}

Samples of tap water were filtered through a cation-exchange membrane Neosepta (Astom Corporation, Japan), spiked with $\mathrm{Cr}$ (III) ions at concentration of $10 \mathrm{ng} / \mathrm{mL}$ and left for equilibration. Before the analysis, samples were adjusted to $\mathrm{pH} 4.5$ using $\mathrm{NaOH}$ and subjected to the IIPs' analyte separation procedures.

Green tea infusion was obtained by immersing the teabag in $200 \mathrm{~mL}$ of Milli Q water or tap water at $80^{\circ} \mathrm{C}$ for $5 \mathrm{~min}$. Then, the infusion was cooled, spiked with $10 \mathrm{ng} / \mathrm{mL}$ of $\mathrm{Cr}$ (III) ions and left for equilibration. After adjusting to $\mathrm{pH} 4.5$, the samples were subjected to the analyte separation procedures on the IIPs.

\section{Results and Discussion}

New solid sorbents-ion imprinted polymers were designed and prepared for selective separation process of $\mathrm{Cr}$ (III) ions from water to determine the analyte by ETAAS. For this purpose $\mathrm{Cr}$ (III)-phen complex, in which the $\mathrm{Cr}$ (III) ion is bonded via a nitrogen donor atom, was imprinted into the polymeric structure through the trapping method using styrene, the neutral functional monomer. As the template molecule was physically immobilized in the polymeric structure, there was a risk of leaching out of the complex during the washing step, which could affect the stability of the binding cavities. Therefore, for preparation of the second polymer, the additional functional monomer, namely 4vinylpyridine (4VP), was introduced to the reaction mixture along with styrene. It was expected that as bifunctional monomer, 4VP was capable of interacting with the 1,10phenentroline ligand's aromatic rings to form $\pi-\pi$ bonds with the polymer matrix. This would allow for the stabilization the specific binding sites and influence the selectivity of prepared polymer. The physicochemical properties of both IIPs were compared and their suitability as SPE material was assessed.

\subsection{The Physicochemical Characteristics of Cr(III) Ion Imprinted Polymers}

The physicochemical properties of the sorbent determine the possibility of its multiuse potential in analyte sorption/desorption cycles in dynamic systems. Sorbents used as a column fillings in the SPE technique should have the appropriate particle size, porosity, mechanical stability and chemical resistance. The particle size affects the degree of sorbent packing in the column and forces the reagent flow rate thus impacting the analysis time. The sorbent porosity determines the specific surface area and the availability of binding sites for the analyte. The stability of sorbents and their resistance to chemical reagents affects the cost and time of analysis.

The particles of IIPs were characterized using scanning electron microscopy (SEM). The particles displayed both irregular shapes and various sizes (120-200 $\mu \mathrm{m})$ and were very hard and, therefore, difficult to crush. The particle surfaces of both IIPs were very smooth (Figure S2). The surface areas of the imprinted and control polymers were derived from adsorption isotherms using the BET (Brunauer, Emmett and Teller) method (Table S1). The BET surface area of the Cr(III)-phen-ST polymer was $365 \mathrm{~m}^{2} / \mathrm{g}$, which is twice as high as that of the Cr(III)-phen-ST-4VP polymer, $177 \mathrm{~m}^{2} / \mathrm{g}$. The pore size of the Cr(III)-phen-ST polymer obtained using the BET method was $1.29 \mathrm{~nm}$, whereas the pore size of the $\mathrm{Cr}(\mathrm{III})$ phen-ST-4VP polymer was lower, $1.21 \mathrm{~nm}$. The values of pore size obtained using BJH (Barrett-Joyner-Halenda) method for IIPs were similar: $2.12 \mathrm{~nm}$ and $2.14 \mathrm{~nm}$, respectively. Therefore, both polymers can be considered as microporous materials. However, the pore volume of the $\mathrm{Cr}$ (III)-phen-ST-4VP polymer, equal to $0.091 \mathrm{~cm}^{3} / \mathrm{g}$, was 2.6-times lower than that of the $\mathrm{Cr}$ (III)-phen-ST polymer, $0.241 \mathrm{~cm}^{3} / \mathrm{g}$. It indicates that introduction of $4 \mathrm{VP}$, an additional functional monomer, generates a steric barrier, resulting in both greater space congestion and denser sorbent packing.

The $\mathrm{Cr}(\mathrm{III})$ ions were efficiently imprinted into the structure of polymers. About $80 \%$ of $\mathrm{Cr}$ (III) ions were imprinted in the $\mathrm{Cr}$ (III)-phen-ST polymer, whereas $70 \%$ were imprinted in the $\mathrm{Cr}$ (III)-phen-ST-4VP polymer (Table S1). However, the amount of imprinted $\mathrm{Cr}$ (III) ions removed from IIPs during the washing step was very small, as only $6 \%$ and $1 \%$ of the 
entrapped $\mathrm{Cr}$ (III) ions were leached from the $\mathrm{Cr}$ (III)-phen-ST and the Cr(III)-phen-ST-4VP polymers, respectively. The significant difference in the leaching of $\mathrm{Cr}$ (III) ions indicates the stronger binding of the template ( $\mathrm{Cr}(\mathrm{III})$-phen complex) in the polymer structure when $4 \mathrm{VP}$ is present, mostly likely due to its interaction with the ligand aromatic rings. Moreover, such low efficiency removal of the imprinted $\mathrm{Cr}$ (III) ions may result in the limited availability of active sites of the polymer for the analyte during the sorption step.

\subsection{The Characteristic of Sorption Properties of Ion Imprinted Polymers}

Sorption of $\mathrm{Cr}$ (III) on a solid sorbent results from the combined effect of the chemical form of the analyte in the sample and of the strength of its interaction with the sorbent's active sites. In order to test the efficiency of separation of $\mathrm{Cr}$ (III) ions on IIPs the retention and elution conditions of the analyte, i.e., the sorbent conditioning procedure, $\mathrm{pH}$ and flow rate of sample, type of eluent, its concentration and flow rate were optimized. Because both IIPs tested have the same template, the same chemical interactions should be responsible for the retention of the analyte. For this reason, the optimization of the analyte separation conditions was performed only on the Cr(III)-phen-ST polymer. Subsequently, the separation of $\mathrm{Cr}$ (III) ions on the $\mathrm{Cr}$ (III)-phen-ST-4VP polymer was checked under the previously established optimal conditions. The selectivity of the polymers towards $\mathrm{Cr}$ (III) ions in the presence of $\mathrm{Cr}(\mathrm{VI})$ and other metal ions coexisting in water as well as the sorption capacity and stability of both tested IIPs were also assessed.

\subsubsection{Optimization of Separation Procedure of Cr(III) Ions on IIPs} Optimization of $\mathrm{Cr}$ (III) Retention Conditions

The $\mathrm{pH}$ of a sample has the greatest influence on the amount of the analyte retained on the IIPs. This is related to the presence of various forms of $\mathrm{Cr}$ (III) in the water environment. In aqueous solutions at a $\mathrm{pH}<4, \mathrm{Cr}$ (III) is present in the form of a kinetically inert aquacomplexes $\mathrm{Cr}\left(\mathrm{H}_{2} \mathrm{O}\right)_{6}{ }^{3+}$. When the $\mathrm{pH}$ increases to $\mathrm{pH} 6$, coordinated water molecules are replaced by more reactive hydroxyl groups, forming more labile neutral or cationic complexes, i.e., $\mathrm{Cr}(\mathrm{OH})_{3 a q}, \mathrm{Cr}\left(\mathrm{H}_{2} \mathrm{O}\right)_{5} \mathrm{OH}^{2+}, \mathrm{Cr}\left(\mathrm{H}_{2} \mathrm{O}\right)(\mathrm{OH})^{2+}$ or $\mathrm{Cr}\left(\mathrm{H}_{2} \mathrm{O}\right)(\mathrm{OH})_{2}{ }^{+}$. In the neutral and slightly alkaline environment, $\mathrm{Cr}(\mathrm{III})$ precipitates in the form $\mathrm{Cr}(\mathrm{OH})_{3(\mathrm{~s})}$, while at a $\mathrm{pH}>9$, the precipitate is transformed into the soluble $\mathrm{Cr}(\mathrm{OH})_{4}{ }^{-}$complex [36].

The effect of the $\mathrm{pH}$ of a sample on the retention of analyte (10 ng of $\mathrm{Cr}$ (III)) on the $\mathrm{Cr}$ (III)-phen-ST polymer was tested in the $\mathrm{pH}$ range from 2.5 to 10.5 (adjusted with $\mathrm{HCl}$ or $\mathrm{NaOH}$ solution) at a flow rate of $1 \mathrm{~mL} / \mathrm{min}$. The absorbance of chromium was measured in the column effluents using the ETAAS technique, and based on this, the efficiency of its sorption was calculated (Figure 2). The sorption of $\mathrm{Cr}(\mathrm{VI})$ ions on the tested sorbent was also studied in order to evaluate its selectivity towards $\mathrm{Cr}$ (III) ions. The study of the retention of $\mathrm{Cr}$ (III) and $\mathrm{Cr}(\mathrm{VI})$ ions was also carried out on the control polymer.

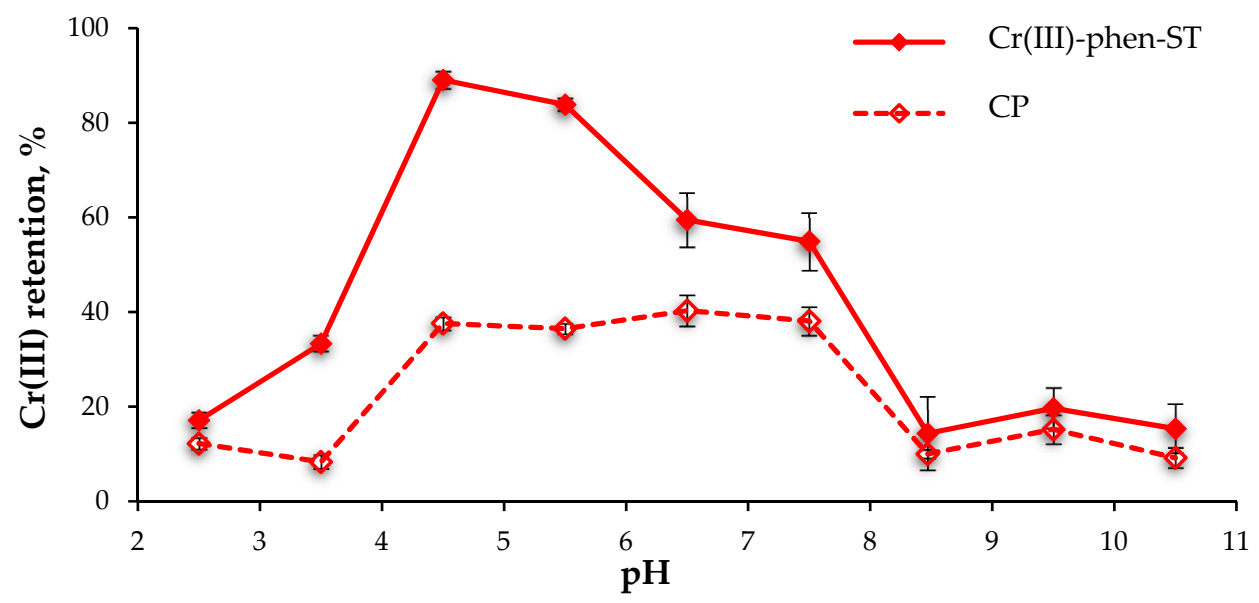

Figure 2. Effect of sample $\mathrm{pH}$ on $\mathrm{Cr}(\mathrm{III})$ retention on the $\mathrm{Cr}(\mathrm{III})$-phen-ST polymer and control polymer (CP) (sample: $10 \mathrm{ng}$ of $\mathrm{Cr}(\mathrm{III}), \mathrm{pH} 4.5$, flow rate: $1.0 \mathrm{~mL} / \mathrm{min}$ ). 
The highest retention of $\mathrm{Cr}(\mathrm{III})$ ions on the $\mathrm{Cr}$ (III)-phen-ST polymer occurred in the solutions of $\mathrm{pH} 4.5(89.1 \pm 1.8 \%, \mathrm{n}=3)$. This may indicate that $\mathrm{Cr}$ (III) ions react with the ligand imprinted into the structure of the polymer under conditions similar to those that form the $\mathrm{Cr}$ (III)-phen complex in ethanol. The lower efficiency of $\mathrm{Cr}$ (III) sorption from solutions at a $\mathrm{pH}<4.5$ probably results from the protonation of the nitrogen atom present in the 1,10-phenantroline ligand, which weakened the interaction of active polymer sites with the cationic form of $\mathrm{Cr}$ (III). A significant decrease of analyte retention from solutions with a $\mathrm{pH}>7.5$ was caused by the lack of interactions between precipitated $\mathrm{Cr}(\mathrm{OH})_{3}$ and the ligand imprinted into polymeric structure. For further studies, pH 4.5 was chosen as the optimal sample solution $\mathrm{pH}$. Under such conditions, the retention of analyte on the $\mathrm{Cr}$ (III)-phen-ST-4VP polymer, prepared with the additional functional monomer, was also high $(87.8 \pm 1.3 \%, \mathrm{n}=3)$.

The retention of the analyte on the control polymers was significantly lower and measured $37.6 \pm 1.4 \%, \mathrm{n}=3$ on CP-ST and $30.3 \pm 1.4 \%, \mathrm{n}=3$ on CP-ST- 4 VP. This indicates a good imprinting effect of both of the polymers prepared with $\mathrm{Cr}$ (III)-phen complex.

The retention of $\mathrm{Cr}(\mathrm{VI})$ from the solution of $\mathrm{pH} 4.5$ was only $12.3 \pm 0.6 \%(\mathrm{n}=3)$ on the $\mathrm{Cr}(\mathrm{III})$-phen-ST polymer and $16.7 \pm 0.9 \%(\mathrm{n}=3)$ on the $\mathrm{Cr}(\mathrm{III})$-fen-ST-4VP polymer, respectively. This demonstrates high selectivity of synthesized sorbents towards the $\mathrm{Cr}$ (III) ions. It was also observed that more than $90 \%$ of the $\mathrm{Cr}(\mathrm{VI})$, which had been retained on the IIPs, was removed with $2 \mathrm{~mL}$ of deionized water. This indicates nonspecific sorption of these ions on the sorbent. The losses of $\mathrm{Cr}(\mathrm{III})$ ions sorbed on IIP during the rinsing of the column with deionized water were negligible $(<2 \%)$.

The method of conditioning the solid sorbent also affects the efficiency of $\mathrm{Cr}$ (III) retention. Most often for conditioning, the solution in which the sample is prepared is recommended. In this work we checked the effect of the $\mathrm{Cr}$ (III)-phen-ST polymer conditioning with deionized water, deionized water of $\mathrm{pH} 4.5(\mathrm{HCl})$ and $0.1 \mathrm{~mol} / \mathrm{L}$ acetate buffer of the $\mathrm{pH}$ 4.5. For this purpose, $1 \mathrm{~mL}$ of conditioning solution at a flow rate of $1 \mathrm{~mL} / \mathrm{min}$ was passed through the polymer columns, followed by $1 \mathrm{~mL}$ of $10 \mathrm{ng} / \mathrm{mL} \mathrm{Cr}$ (III) standard solution. The highest efficiency of $\mathrm{Cr}$ (III) retention, equal to $86.7 \pm 2.9 \%(\mathrm{n}=3)$, was obtained on the $\mathrm{Cr}$ (III)-phen-ST polymer conditioned with deionized water. The same analyte retention efficiency was obtained on sorbent conditioning with deionized water at $\mathrm{pH} 4.5$, but, in that case, the repeatability was lower $(86.6 \pm 5.7 \%, \mathrm{n}=3)$. When a $0.1 \mathrm{~mol} / \mathrm{L}$ acetate buffer solution was used, the $\mathrm{Cr}$ (III) retention on the sorbent bed decreased by $25 \%$. This could be due to the presence of acetate ions in the column, which compete in the interaction between $\mathrm{Cr}$ (III) ions and the active sites of sorbents. In further studies, the columns were conditioned with $1 \mathrm{~mL}$ of deionized water.

The influence of sample flow rate on the retention of $\mathrm{Cr}$ (III) on the $\mathrm{Cr}$ (III)-phen-ST polymer was investigated in a range from 0.25 to $2.0 \mathrm{~mL} / \mathrm{min}$. The highest $\mathrm{Cr}$ (III) retention $(90 \%)$ was observed at the sample flow rate of $1.0 \mathrm{~mL} / \mathrm{min}$. The increase of a sample flow rate to $1.5 \mathrm{~mL} / \mathrm{min}$ and $2 \mathrm{~mL} / \mathrm{min}$ caused a decrease of $\mathrm{Cr}$ (III) retention by a maximum of $9 \%$, whereas reduction of a flow rate did not influence the retention of analyte. The optimal flow rates of samples on the $\mathrm{Cr}$ (III)-phen-ST and the $\mathrm{Cr}$ (III)-phen-ST-4VP polymers was assumed to be $1.0 \mathrm{~mL} / \mathrm{min}$.

\section{Optimization of Elution of $\mathrm{Cr}$ (III) Conditions}

The efficient elution of the analyte retained on the IIP polymer enables multiple uses. Therefore, it is essential to find a suitable eluent that will ensure a quantitative elution of $\mathrm{Cr}$ (III) ions and will not affect the properties of the sorbent. In order to optimize the $\mathrm{Cr}$ (III) elution conditions, the eluent solutions of various concentrations, volumes and flow rates were tested.

Reagents' complexing $\mathrm{Cr}(\mathrm{III})$ ions, namely EDTA $\left(\log \beta_{1}=23.4\right)$ and acetic acid ( $\log$ $\left.\beta_{1}=4.63\right)$, were tested as eluents. For elution of the analyte retained on the $\mathrm{Cr}(\mathrm{III})$-phen-ST polymer, either $1 \mathrm{~mL}$ and $2 \mathrm{~mL}$ of EDTA solution at concentration of $0.05-0.2 \mathrm{~mol} / \mathrm{L}$ or $\mathrm{CH}_{3} \mathrm{COOH}$ solution at concentration of $0.1 \mathrm{~mol} / \mathrm{L}$ was used. It was observed that the 
elution of $\mathrm{Cr}(\mathrm{III})$ ions with $1 \mathrm{~mL}$ of the $0.1 \mathrm{~mol} / \mathrm{L}$ EDTA solution was $102.5 \pm 3.9 \%(\mathrm{n}=3)$, while the elution with $2 \mathrm{~mL}$ of the $0.1 \mathrm{~mol} / \mathrm{L} \mathrm{CH}_{3} \mathrm{COOH}$ solution was $90.0 \pm 5.7 \%(\mathrm{n}=3)$ (Figure 3).

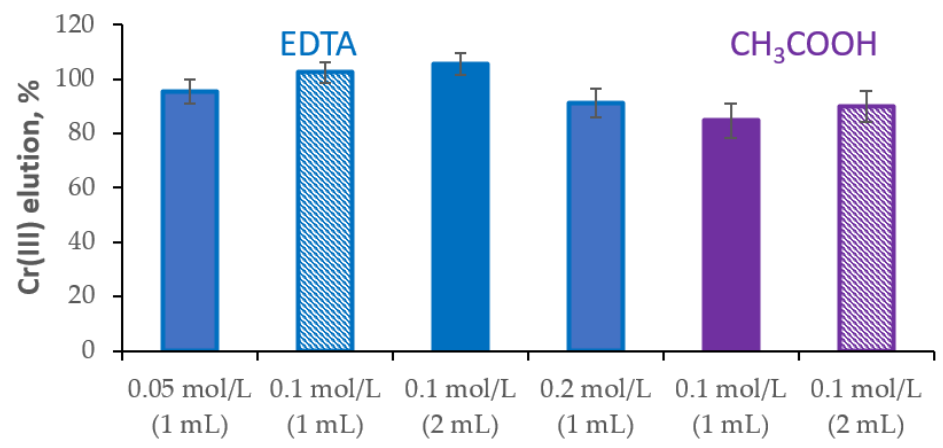

Figure 3. Effect of various eluents, their concentration and volume on the $\mathrm{Cr}(\mathrm{III})$ elution from the $\mathrm{Cr}$ (III)-phen-ST polymer (sample: $10 \mathrm{ng}$ of $\mathrm{Cr}(\mathrm{III}), \mathrm{pH} 4.5$, flow rate: $1.0 \mathrm{~mL} / \mathrm{min}$ ).

Increasing the EDTA concentration to $0.2 \mathrm{~mol} / \mathrm{L}$ adversely affected the elution of $\mathrm{Cr}$ (III) from the sorbent, reducing it by $11 \%$. The use of a smaller volume of $\mathrm{CH}_{3} \mathrm{COOH}$ reduced the efficiency of analyte elution by $5 \%$. Therefore, $1 \mathrm{~mL}$ of the $0.1 \mathrm{~mol} / \mathrm{L}$ EDTA solution was selected for further studies, as it resulted in the optimal elution of $\mathrm{Cr}$ (III) ions from the $\mathrm{Cr}(\mathrm{III})$-phen-ST polymer.

The influence of the eluent flow rate on the elution efficiency of $\mathrm{Cr}$ (III) from the $\mathrm{Cr}$ (III)phen-ST polymer was investigated in a range from 0.25 to $2.0 \mathrm{~mL} / \mathrm{min}$. It was found that the highest analyte elution $(96.6 \pm 1.3 \%, \mathrm{n}=3)$ was obtained using the eluent flow rate of $1.0 \mathrm{~mL} / \mathrm{min}$. Therefore, it was selected as the optimal rate. The increase of the flow rate up to $2 \mathrm{~mL} / \mathrm{min}$ reduced the elution of $\mathrm{Cr}$ (III) ions by $15 \%$. The use of a lower flow rate did not significantly influence the elution efficiency of $\mathrm{Cr}$ (III) from IIP. Under optimal conditions, the elution efficiency of the analyte from the $\mathrm{Cr}(\mathrm{III})$-phen-ST-4VP polymers was equal to $93.9 \pm 3.4 \%(n=3)$.

\subsubsection{Selectivity of IIPs towards Cr(III) Ions}

The selectivity of the sorbent determines the sorbent's ability to retain one form of chromium (analyte) in the presence of other ions, also $\mathrm{Cr}(\mathrm{VI})$, present in the sample. This can be expressed as a selectivity coefficient $(\alpha)$ and relative selectivity coefficient ( $\left.\alpha^{\prime}\right)$ (for definitions see Section 2.4). The selectivity of tested IIPs towards $\mathrm{Cr}$ (III) ions was studied in the presence of $\mathrm{Cu}(\mathrm{II}), \mathrm{Mn}$ (II) and $\mathrm{Fe}(\mathrm{III})$ ions, which have an ionic radius similar to $\mathrm{Cr}$ (III) and therefore can compete with $\mathrm{Cr}$ (III) ions in the formation of complexes with the 1,10-phenenthroline ligand imprinted into the polymer structure. It was observed that the $\mathrm{Cr}$ (III)-phen-ST polymer showed good selectivity towards $\mathrm{Cr}$ (III) ions in the presence of $\mathrm{Cu}$ (II) and Fe(III) ions, but lower selectivity in the presence of $\mathrm{Mn}$ (II) ions (Table 2). The $\mathrm{Cr}$ (III)-phen-ST-4VP polymer turned out to be more selective for $\mathrm{Cr}$ (III) ions. The selectivity coefficients $\alpha$ of the $\mathrm{Cr}(\mathrm{III})$-phen-ST-4VP polymer in the presence of $\mathrm{Cu}(\mathrm{II}), \mathrm{Fe}(\mathrm{III})$ and $\mathrm{Mn}(\mathrm{II})$ ions increased by 1.3 times, 1.6 times and 40 times, respectively. The introduction of $4 \mathrm{VP}$, an additional functional monomer, resulted both in better entrapment of the complex in the polymer structure and in the formation of more selective binding sites. The smaller BET surface area and pore volume of this polymer indicate a lower availability of active sites for other metal ions; therefore, only the analyte ions can be bound at these sites. 
Table 2. Selectivity coefficient $(\alpha)$ and relative selectivity coefficient ( $\left.\alpha^{\prime}\right)$ of the IIPs towards $\mathrm{Cr}$ (III) ions in the presence of competitive ions (sample: $10 \mathrm{ng}$ of $\mathrm{Cr}(\mathrm{III})+10 \mathrm{ng}$ of other metal ion).

\begin{tabular}{ccccc}
\hline \multirow{2}{*}{ Metal Ion, Me } & \multicolumn{2}{c}{ Cr(III)-Phen-ST } & \multicolumn{2}{c}{ Cr(III)-Phen-ST-4VP } \\
\cline { 2 - 5 } & $\boldsymbol{\alpha}$ & $\boldsymbol{\alpha}^{\prime}$ & $\boldsymbol{\alpha}$ & $\boldsymbol{\alpha}^{\prime}$ \\
\hline $\mathrm{Cu}(\mathrm{II})$ & $16.7 \pm 0.1$ & $6.4 \pm 0.7$ & $21.8 \pm 0.9$ & $10.2 \pm 1.3$ \\
$\mathrm{Mn}(\mathrm{II})$ & $4.4 \pm 0.4$ & $1.2 \pm 0.3$ & $175.5 \pm 8.5$ & $26.2 \pm 6.2$ \\
$\mathrm{Fe}(\mathrm{III})$ & $9.6 \pm 0.1$ & $9.0 \pm 1.5$ & $15.4 \pm 2.6$ & $12.0 \pm 2.3$ \\
\hline
\end{tabular}

The relative selectivity coefficients showed that the Cr(III)-phen-ST $\left(\alpha^{\prime}=1.2-9.0\right)$ and the $\mathrm{Cr}$ (III)-phen-ST-4VP $\left(\alpha^{\prime}=10.2-26.2\right)$ polymers were more selective towards $\mathrm{Cr}$ (III) ions with respect to control polymers. The obtained values of selectivity coefficients $\left(\alpha, \alpha^{\prime}\right)$ for $\mathrm{Cr}$ (III) were similar to these reported for $\mathrm{Cr}$ (III)-IIPs in the literature (see Table 1) $[23,24,32]$.

\subsubsection{Sorption Capacity and Stability of IIPs}

Due to the physicochemical properties of IIPs, each portion of the polymers required up to 15 cycles of preliminary conditioning in order to activate the binding sites in the polymer structure and to achieve the appropriate sorption properties.

The sorption capacity obtained for the $\mathrm{Cr}(\mathrm{III})$-phen-ST polymer was $1.18 \mu \mathrm{g} / \mathrm{g}$. The introduction of $4 \mathrm{VP}$, an additional functional monomer, decreased the sorption capacity of the Cr(III)-phen-ST-4VP polymer three fold (to $0.41 \mu \mathrm{g} / \mathrm{g}$ ). As mentioned above (Section 2.3), the lower removal efficiency of imprinted $\mathrm{Cr}$ (III) ions from the polymer in the washing step led to the formation of a porous structure with a low pore volume. This, in turn, caused limited availability of active sites for analyte sorption. The sorption capacities obtained for the tested IIPs were low but were comparable with other IIPs used for the separation and determination of trace amounts of $\mathrm{Cr}$ (III) by the ETAAS technique [27].

The stability and reusability of the sorbents were studied in repeated sorption and desorption cycles performed at optimal conditions. On the Cr(III)-phen-ST polymer, the retention $(86.5 \pm 3.3 \%)$ and recovery $(85.6 \pm 4.0 \%)$ of the analyte remained constant for up to 107 successive separation cycles. This indicates the high stability of that polymer and its possibility for multiple uses. The $\mathrm{Cr}(\mathrm{III})$-phen-ST-4VP polymer can be used continuously for 75 cycles without losing its sorption properties, as the average retention of $\mathrm{Cr}$ (III) during that time was $83.9 \pm 4.7 \%$. The reproducibility of analyte retention rate during the stability studies of IIPs, expressed as the RSD (relative standard deviation), ranged from $3.8 \%$ to $5.6 \%$. In respect to stability, the tested IIPs were superior to other Cr-imprinted polymers, which retained their sorption/desorption properties for only five or ten cycles (see Table 1) [23,33]. However, the $\mathrm{Cr}$ (III)-IIPs previously prepared in our group are characterized by similar [24] or better stability $[25,27]$ to the tested polymers (see Table 1). The lower stability of the $\mathrm{Cr}$ (III)-phen-ST-4VP polymer as compared to the Cr(III)-phen-ST polymer was likely caused by the presence of lower amounts of initial active sites in the polymeric structure due to weaker leaching of the imprinted ions during the washing step (Table S1). The elution of $\mathrm{Cr}(\mathrm{III})$ ions with the eluent solution in subsequent cycles led to the removal of the ligand from the polymeric structure and loss of its sorption properties. Thus, the stronger binding of the ligand to the polymer structure affects the stability of the polymer, while the weaker interaction of the imprinted ions with the ligand allows for multiple retention/elution of the analyte.

\subsection{Analytical Performance of Methods}

The analytical performance of the developed methods, based on the separation of $\mathrm{Cr}$ (III) ions on the $\mathrm{Cr}$ (III)-phen-ST and the $\mathrm{Cr}$ (III)-phen-ST-4VP polymers prior to determination of $\mathrm{Cr}$ by ETAAS, was evaluated in optimized experimental conditions. The separation of $\mathrm{Cr}$ (III) ions on both polymers was characterized by high retention efficiency and recovery of the analyte (Table 3). The repeatability of the Cr(III) ions' separation on the 
IIPs for six subsequent cycles was better than 3.6\%, expressed as the RSD of the analyte recovery.

Table 3. Characteristic of the separation process of $\mathrm{Cr}$ (III) ions on IIPs under optimal conditions (sample: pH 4.5, FR $1 \mathrm{~mL} / \mathrm{min}$; elution: $1 \mathrm{~mL}$ of $0.1 \mathrm{~mol} / \mathrm{L}$ EDTA, FR $1 \mathrm{~mL} / \mathrm{min}$, mean value $\pm \mathrm{SD}$, $\mathrm{n}=6$ ).

\begin{tabular}{ccc}
\hline & Cr(III)-Phen-ST & Cr(III)-Phen-ST-4VP \\
\hline Retention of $\mathrm{Cr}(\mathrm{III}) \pm \mathrm{SD}, \%, \mathrm{n}=6$ & $92.9 \pm 1.0$ & $91.6 \pm 1.4$ \\
Elution of $\mathrm{Cr}(\mathrm{III}) \pm \mathrm{SD}, \%, \mathrm{n}=6$ & $96.6 \pm 1.3$ & $97.6 \pm 1.9$ \\
Recovery of $\mathrm{Cr}(\mathrm{III}) \pm \mathrm{SD}, \%, \mathrm{n}=6$ & $91.7 \pm 1.8$ & $93.9 \pm 3.4$ \\
Sorption capacity, $\mu \mathrm{g} / \mathrm{g}$ & 1.18 & 0.41 \\
Stability, number of cycles & 107 & 75 \\
\hline
\end{tabular}

Calibration graphs were prepared by passing standard $\mathrm{Cr}$ (III) solutions of different concentrations through columns filled with IIPs under optimal conditions. It was found that calibration graphs of $\mathrm{Cr}(\mathrm{III})$ were linear in the concentration range from $0.5 \mathrm{ng} / \mathrm{mL}$ to $20 \mathrm{ng} / \mathrm{mL}$ given the following regression equation: $\mathrm{y}=0.0153 \mathrm{x}+0.0251, \mathrm{R}^{2}=0.9992$ and $y=0.0104 x+0.0304, R^{2}=0.9989$. The limits of detection (LOD) and quantification (LOQ) of the methods were calculated according to IUPAC recommendation [37] as LOD $=3 \mathrm{SD}_{\text {blank }} / \mathrm{a}$, and $\mathrm{LOQ}=10 \mathrm{SD}_{\text {blank }} / \mathrm{a}$, where $\mathrm{SD}_{\text {blank }}$ is the standard deviation of the absorbance of blank sample, while $a$ is the slope of the calibration graph. The values of LOD: $0.35 \mathrm{ng} / \mathrm{mL}$ and $0.47 \mathrm{ng} / \mathrm{mL}$, and LOQ: $1.18 \mathrm{ng} / \mathrm{mL}$ and $1.55 \mathrm{ng} / \mathrm{mL}$ obtained using the $\mathrm{Cr}$ (III)-phen-ST and the Cr(III)-phen-ST-4VP polymers, respectively.

The ability of the IIPs to preconcentrate $\mathrm{Cr}(\mathrm{III})(1 \mathrm{ng} / \mathrm{mL})$ from various sample volumes (1-20 mL) was also studied (Table 4). It was found that for $20 \mathrm{~mL}$ of sample, the recovery of analyte on the Cr(III)-phen-ST polymer was $87.4 \pm 4.3 \%(\mathrm{n}=5)$, while on the $\mathrm{Cr}(\mathrm{III})$ phen-ST-4VP polymer it was $84.8 \pm 1.4 \%(n=5)$. This results in a 20 -fold preconcentration of $\mathrm{Cr}$ (III) ions and decreases the LOD of the method to $0.018 \mathrm{ng} / \mathrm{mL}$ and $0.024 \mathrm{ng} / \mathrm{mL}$, respectively. The obtained values of LOD were comparable to those found in literature, when ETAAS or a very sensitive ICP-MS technique was applied for determination of analyte (see Table 1). The LOD values after separation of $\mathrm{Cr}$ (III) on tested IIPs seems to be sufficient for analysis of natural water samples.

Table 4. Recovery of $\mathrm{Cr}$ (III) after separation procedure on the IIPs from various model solutions (sample: pH 4.5, FR $1 \mathrm{~mL} / \mathrm{min}$; elution: $1 \mathrm{~mL}$ of $0.1 \mathrm{~mol} / \mathrm{L}$ EDTA, FR $1 \mathrm{~mL} / \mathrm{min}$, mean value $\pm \mathrm{SD}$ ).

\begin{tabular}{|c|c|c|}
\hline \multirow{2}{*}{ Model Sample } & Cr(III)-Phen-ST & Cr(III)-Phen-ST-4VP \\
\hline & \multicolumn{2}{|c|}{ Recovery of $\mathrm{Cr}(\mathrm{III}) \pm \mathrm{SD}, \%, \mathrm{n}=5$} \\
\hline $1 \mathrm{~mL}$ of $1 \mathrm{ng} / \mathrm{mL} \mathrm{Cr}(\mathrm{III})$ & $94.5 \pm 4.9$ & $89.6 \pm 4.0$ \\
\hline $10 \mathrm{~mL}$ of $1 \mathrm{ng} / \mathrm{mL} \mathrm{Cr}(\mathrm{III})$ & $99.3 \pm 1.8$ & $82.9 \pm 5.2$ \\
\hline $20 \mathrm{~mL}$ of $1 \mathrm{ng} / \mathrm{mL} \mathrm{Cr}(\mathrm{III})$ & $87.4 \pm 4.3$ & $84.8 \pm 1.4$ \\
\hline 10 ng $\mathrm{Cr}(\mathrm{III})+10$ ng $\mathrm{Cr}(\mathrm{VI})$ & $84.5 \pm 2.9$ & $99.2 \pm 4.7$ \\
\hline 10 ng Cr(III) + 20 ng Cr(VI) & $82.7 \pm 2.4$ & $96.0 \pm 3.8$ \\
\hline 10 ng $\mathrm{Cr}(\mathrm{III})+50$ ng $\mathrm{Cr}(\mathrm{VI})$ & $100.0 \pm 4.6$ & $84.3 \pm 2.2$ \\
\hline 10 ng Cr(III) + 100 ng Cr(VI) & $86.7 \pm 2.1$ & $84.8 \pm 1.6$ \\
\hline
\end{tabular}

The procedures that use the Cr(III)-phen-ST and the Cr(III)-phen-ST-4VP polymers were applied to separate the $\mathrm{Cr}(\mathrm{III})$ and $\mathrm{Cr}(\mathrm{VI})$ ions from solutions containing different concentrations of these ions (listed in Table 4). It was found that using the Cr(III)-phen-ST polymer allowed for the recovery of $\mathrm{Cr}$ (III) in the range of $83-100 \%$ in mixtures containing various ratios of $\mathrm{Cr}(\mathrm{III})$ and $\mathrm{Cr}(\mathrm{VI})$ ions. In the case of the $\mathrm{Cr}$ (III)-phen-ST-4VP polymer, recovery values of $\mathrm{Cr}(\mathrm{III})$ ranged from $85 \%$ to $99 \%$ in solutions with an excess of $\mathrm{Cr}(\mathrm{VI})$ ions. It was observed that with an increase in the excess of $\mathrm{Cr}(\mathrm{VI})$ ions, the recovery of $\mathrm{Cr}(\mathrm{III})$ ions on the $\mathrm{Cr}(\mathrm{III})$-phen-ST-4VP polymer slightly decreased. The specific binding sites of 
$\mathrm{Cr}(\mathrm{III})$ ions were, potentially, partially blocked by $\mathrm{Cr}(\mathrm{VI})$ ions, due to the lower sorption capacity of this sorbent. The obtained results are characterized by good repeatability (RSD $<5 \%$ ). Both polymers demonstrated good characteristic for the separation of $\mathrm{Cr}$ (III) in the presence of $\mathrm{Cr}(\mathrm{VI})$ ions, which is an advantage of the prepared IIPs over other imprinted polymers, where $\mathrm{Cr}(\mathrm{III})$ and $\mathrm{Cr}(\mathrm{VI})$ ions were retained simultaneously [23,30].

The accuracy of the proposed methods was evaluated by analyzing the standard reference materials of surface water SRM 1643e (NIST, USA) with the certified value for total concentration of chromium. The presence of only $\mathrm{Cr}$ (III) ions in this material was previously confirmed in the literature [38,39]. The concentrations of Cr(III) in SRM 1643e (2- and 4-fold diluted) determined after separation of analyte on both polymers were in good agreement with the certified value for the total concentration of chromium (recovery in the range of 93.3 to $98.6 \%$, Table 5), thus indicating the good accuracy of the proposed SPE-ETAAS methods.

Table 5. Recovery of Cr(III) from samples of water on the IIPs (sample:1 mL, pH 4.5, FR $1 \mathrm{~mL} / \mathrm{min}$; elution: $0.1 \mathrm{~mol} / \mathrm{L}$ EDTA, FR $1 \mathrm{~mL} / \mathrm{min}$, mean value $\pm \mathrm{SD}$ ).

\begin{tabular}{|c|c|c|c|}
\hline \multirow{2}{*}{ Sample } & \multirow{2}{*}{$\begin{array}{l}\text { Added Mass of } \\
\text { Cr(III), ng }\end{array}$} & Cr(III)-Phen-ST & Cr(III)-Phen-ST-4VP \\
\hline & & \multicolumn{2}{|c|}{ Recovery of $\mathrm{Cr}(\mathrm{III}) \pm \mathrm{SD}, \%, \mathrm{n}=5$} \\
\hline Surface water SRM $1643 \mathrm{e}^{\mathrm{a}}$, & b 5.1 & $93.4 \pm 3.5$ & $98.7 \pm 3.6$ \\
\hline $\mathrm{n}=5$ & b 10.2 & $93.9 \pm 1.6$ & $96.9 \pm 4.6$ \\
\hline Tap water, $\mathrm{n}=4$ & 10 & $35.2 \pm 0.9$ & $37.8 \pm 1.2$ \\
\hline Tap water ${ }^{\mathrm{C}}, \mathrm{n}=4$ & 10 & $75.3 \pm 4.1$ & $60.0 \pm 1.4$ \\
\hline Tap water (filtered), $\mathrm{n}=5$ & 10 & $93.2 \pm 8.5$ & $79.3 \pm 8.6$ \\
\hline $\begin{array}{l}\text { Green tea infusion in } \\
\text { Milli-Q water, } \mathrm{n}=6\end{array}$ & 10 & $98.6 \pm 3.2$ & $69.1 \pm 3.9$ \\
\hline $\begin{array}{l}\text { Green tea infusion in tap } \\
\text { water, } n=6\end{array}$ & 10 & $94.2 \pm 2.0$ & $43.6 \pm 4.7$ \\
\hline
\end{tabular}

a surface water SRM 1643e-certified value of Cr: $20.40 \pm 0.24 \mathrm{ng} / \mathrm{mL}, \mathrm{k}=2{ }^{\mathrm{b}}$ mass of Cr loaded on IIPs after 4- and 2-fold dilution of SRM $1643 \mathrm{e} .{ }^{\mathrm{c}}$ mass of IIPs increased to $1 \mathrm{~g}$.

\subsection{Testing of the Method for Analysis of Water Samples}

Methods were applied in determining of $\mathrm{Cr}$ (III) ions in surface water, tap water and green tea infusions. Green tea was chosen as a popular drink consumed by people, because it is rich in antioxidants and minerals and has a positive effect on the human body. However, there are reports in the literature [40-42] about the presence of heavy metals, including chromium, in tea leaves.

Samples were adjusted to $\mathrm{pH} 4.5$, left for equilibration and then submitted to the separation on both IIPs. As can be seen in Table 5, the recovery of $\mathrm{Cr}$ (III) from surface water (SRM 1643e) was quantitative. Because the concentration of $\mathrm{Cr}$ (III) in tap water samples and green tea infusions was below the LOQ of the methods, the procedures were applied to samples spiked with $\mathrm{Cr}$ (III) at a concentration of $10 \mathrm{ng} / \mathrm{mL}$. However, the recovery of $\mathrm{Cr}$ (III) in tap water was below $40 \%$ (Table 5), which indicates a significant effect of sample constituents. Since the destruction of the organic matrix of the tap water sample with UV radiation did not improve the $\mathrm{Cr}$ (III) recovery, we assumed that this effect was due to the presence of inorganic ions in the water. Therefore, the columns were filled with bigger masses of polymers $(0.4 \mathrm{~g}$ and $1 \mathrm{~g}$ vs. $0.1 \mathrm{~g})$, which resulted in higher, but still not quantitative (60-75\%), recovery of the analyte from tap water (Table 5). Next, we compared the total content of following elements: $\mathrm{Ca}, \mathrm{Mg}, \mathrm{Cu}, \mathrm{Fe}, \mathrm{Mn}, \mathrm{Zn}$ and $\mathrm{Ni}$, in tap water, determined by ICP-MS technique, with their content in SRM surface water (taken from the certificate). We found that the sample of tap water loaded on the column contained 3.2 times higher content of these metals than sample of surface water (after 2-fold dilution) $(63 \mathrm{mg} / \mathrm{L}$ vs. $20 \mathrm{mg} / \mathrm{L})$. In order to check whether the reason for the incomplete recovery was an excess of other ions, water was filtered through the cation-exchange membrane. It allowed to reduce the content of other metal ion in the sample by $37 \%$ (to $40 \mathrm{mg} / \mathrm{L}$ ) and resulted in quantitative recovery of $\mathrm{Cr}$ (III) on $0.1 \mathrm{~g}$ mass of $\mathrm{Cr}$ (III)-phen-ST polymer 
$(93.2 \pm 8.5 \%)$. Analogous experiments were performed for infusions of green tea prepared in Milli Q water and filtered tap water showing good recovery of $\mathrm{Cr}(\mathrm{III})$ from such samples on $\mathrm{Cr}$ (III)-phen-ST polymer $(98.6 \pm 3.2 \%$ and $94.2 \pm 2.0 \%)$.

As shown in Table 5, lower Cr(III) recovery from almost all samples was observed on the $\mathrm{Cr}$ (III)-phen-ST-4VP polymer, which is most likely the result of its lower sorption capacity than the $\mathrm{Cr}(\mathrm{III})$-fen-ST polymer $(0.4 \mu \mathrm{g} / \mathrm{g}$ versus $1.18 \mu \mathrm{g} / \mathrm{g})$. It can be assumed that metal cations remaining in the water sample after filtration underwent non-specific sorption on the $\mathrm{Cr}$ (III)-phen-ST-4VP polymer, overloading of the capacity of this sorbent and decreasing its sorption ability for $\mathrm{Cr}$ (III) ions. This effect was not observed during separation of $\mathrm{Cr}$ (III) ions from surface water SRM 1643e which contained from 3 to 6 -times lower content of metals than tap water samples.

Summarizing, the developed method using the Cr(III)-phen-ST polymer is characterized by good separation properties of $\mathrm{Cr}$ (III) ions, exceeding some procedures published in the literature (see Table 1) [23,33]. The prepared polymer allows for efficient of $\mathrm{Cr}$ (III) retention and elution with a fast sorption and desorption process of the analyte, making it suitable for working in a dynamic mode. The high stability of the $\mathrm{Cr}$ (III)-phen-ST polymer is its additional advantage compared to the sorbents used in the static mode [23,33]. This allows for multiple uses of the sorbent, which reduces the time and cost of the analysis. The $\mathrm{Cr}$ (III)-phen-ST polymer is also characterized by good selectivity towards $\mathrm{Cr}(\mathrm{III})$ ions in the presence of $\mathrm{Fe}(\mathrm{III}), \mathrm{Mn}(\mathrm{II}), \mathrm{Cu}(\mathrm{II})$ and $\mathrm{Cr}(\mathrm{VI})$ ions. Among the limitations of the procedure, the most serious is its susceptibility to the high content of other metal ions (mainly $\mathrm{Ca}$ and $\mathrm{Mg}$ ) commonly present in water samples, which reduces the sorption capacity of the polymer towards $\mathrm{Cr}$ (III) ions, probably due to blocking the active site of the sorbent. The procedure could be useful for studies of chromium speciation in tea infusions.

\section{Conclusions}

In this research, a new dynamic SPE procedure was developed for the separation of $\mathrm{Cr}$ (III) ions from water samples prior to analyte determination by ETAAS. The new IIPs were designed and used as solid sorbents for the separation of $\mathrm{Cr}$ (III) ions in a dynamic mode. They were obtained by imprinting of a $\mathrm{Cr}$ (III)-phen complex in the presence of two functional monomers: styrene or styrene and 4-vinylpyridine. Both IIPs have the ability to separate $\mathrm{Cr}(\mathrm{III})$ from an aqueous solution at $\mathrm{pH} 4.5(\mathrm{Cr}$ (III) recovery $>92 \%)$, and are characterized by good stability and selectivity towards $\mathrm{Cr}(\mathrm{III})$ in the presence of $\mathrm{Cr}(\mathrm{VI})$ ions. It was found that adding of $4 \mathrm{VP}$, an additional functional monomer, resulted in stronger binding of the $\mathrm{Cr}$ (III)-phen complex within polymeric matrix, which influenced its physicochemical properties. The Cr(III)-phen-ST-4VP polymer has a lower surface area, pore size, pore volume, and sorption capacity in comparison to the $\mathrm{Cr}(\mathrm{III})$-phen-ST polymer, but a higher selectivity towards $\mathrm{Cr}(\mathrm{III})$ ions in the presence of $\mathrm{Cu}(\mathrm{II}), \mathrm{Mn}(\mathrm{II})$ and Fe(III) ions. These properties limit its application for analysis of water samples. This study also has shown that the physicochemical properties significantly affect the suitability of IIP polymers for the separation of analytes from real samples. Better performance of the $\mathrm{Cr}$ (III)-phen-ST polymer was found for the separation of the $\mathrm{Cr}(\mathrm{III})$ from tea infusions.

The ETAAS method based on using the $\mathrm{Cr}$ (III)-phen-ST polymer was characterized by good repeatability, sensitivity and assurance of effective separation of the analyte and its accurate determination from samples with moderate content of matrix ions, such as tea infusions.

Supplementary Materials: The following supporting information can be downloaded at: https: / / www.mdpi.com/article/10.3390/w14040529/s1, Figure S1: FT-IR spectra of the Cr(III)-phen-ST polymer and the $\mathrm{Cr}$ (III)-phen-ST-4VP polymer; Figure S2. SEM images of the surface particles of the $\mathrm{Cr}$ (III)-phen-ST polymer, the Cr(III)-phen-ST-4VP polymer and control polymers; Table S1. Efficiency of imprinting/leaching of $\mathrm{Cr}$ (III) from IIPs and structural parameters of the $\mathrm{Cr}(\mathrm{III})$-phen-ST, the $\mathrm{Cr}(\mathrm{III})$-phen-ST-4VP and control polymers determined by nitrogen adsorption-desorption isotherm. 
Author Contributions: Conceptualization, B.G.-Ż., L.T. and B.L.; Investigation, L.T.; Methodology, L.T., B.L. and B.G.-Ż.; Supervision, B.G.-Ż.; Validation, L.T. and B.L.; Visualization, L.T.; Writingoriginal draft, B.L.; Writing-review \& editing, B.L. and B.G.-Ż. All authors have read and agreed to the published version of the manuscript.

Funding: Research work financed by the Ministry of Science and Education as part of a grant for maintaining research potential awarded to the Faculty of Chemistry, University of Bialystok.

Institutional Review Board Statement: Not applicable.

Informed Consent Statement: Not applicable.

Data Availability Statement: Not applicable.

Acknowledgments: The authors kindly acknowledge A.Z. Wilczewska (University of Bialystok, Department of Chemistry) for assistance in preparation of IIPs. The surface area and porosity analyser and scanning electron microscope were funded by EU, as part of the Operational Programme Development of Eastern Poland 2007-2013, project: POPW.01.03.00-20-034/09-00.

Conflicts of Interest: The authors declare no conflict of interest.

\section{References}

1. Dhal, B.; Thatoi, H.N.; Das, N.N.; Pandey, B.D. Chemical and microchemical remediation of hexavalent chromium from contaminated soil and mining/metallurgical solid waste: A review. J. Hazard. Mater. 2013, 250-251, 272-291. [CrossRef] [PubMed]

2. Sawicka, E.; Jurkowska, K.; Piwowar, A. Chromium(III) and chromium(VI) as important players in the induction of gentoxicityCurrent view. Ann. Agric. Environ. Med. 2021, 28, 1-10. [CrossRef] [PubMed]

3. Metze, D.; Jakubowski, N.; Klockow, D. Speciation of chromium in environment and food. In Handbook of Elemental Speciation II: Species in the Environment, Food, Medicine and Occupational Health; Cornelis, R., Crews, H., Caruso, J., Heumann, K.G., Eds.; John Wiley and Sons, Ltd.: Chichester, UK, 2005; pp. 120-134.

4. Vincent, J.B. New evidence against chromium as an essential trace element. J. Nutr. 2017, 147, 2212-2219. [CrossRef] [PubMed]

5. EFSA NDA Panel (EFSA Panel on Dietetic Products, Nutrition and Allergies). Scientific opinion on Dietary Reference Values for chromium. EFSA J. 2014, 12, 3845. [CrossRef]

6. Staniek, H.; Krejpcio, Z.; Wieczorek, D. The effects of high dietary doses of chromium(III) complex with propionic acid on nutritional and selected blood indices in healthy female rats. Biol. Trace. Elem. Res. 2016, 171, 192-200. [CrossRef] [PubMed]

7. Fang, Z.; Zhao, M.; Zhen, H.; Chen, L.; Shi, P.; Huang, Z. Genotoxicity of tri- and hexavalent chromium compounds in vivo and their modes of action on DNA damage in vitro. PLoS ONE 2014, 9, e103194. [CrossRef] [PubMed]

8. Kotaś, J.; Stasicka, Z. Chromium occurrence in the environment and methods of its speciation. Environ. Pollut. 2000, 107, 263-283. [CrossRef]

9. Kumar, R.A.; Riyazuddin, P. Chromium speciation in a contaminated groundwater: Redox processes and temporal variability. Environ. Monit. Assess. 2011, 176, 647-662. [CrossRef]

10. Bakshi, A.; Panigrahi, A.K. A comprehensive review on chromium induced alterations in fresh water fishes. Toxicol. Rep. 2018, 5, 440-447. [CrossRef]

11. European Council, Council Directive 98/83/EC of 3 November 1998 on the Quality of Water Intended for Human Consumption. Off. J. 1998, L330, 32-54.

12. Spanu, D.; Monticelli, D.; Binda, G.; Dossi, C.; Rampazzi, L.; Recchia, S. One-minute highly selective Cr(VI) determination at ultra-trace levels: An ICP-MS method based on the on-line trapping of Cr(III). J. Hazard. Mat. 2021, 412, 125280. [CrossRef] [PubMed]

13. Wani, A.A.; Khan, A.M.; Manea, Y.K.; Salem, M.A.S.; Shahadat, M. Selective adsorption and ultrafast fluorescent detection of $\mathrm{Cr}(\mathrm{VI})$ in wastewater using neodymium doped polyaniline supported layered double hydroxide nanocomposite. J. Hazard. Mat. 2021, 416, 125754. [CrossRef] [PubMed]

14. Trzonkowska, L.; Leśniewska, B.; Godlewska-Żyłkiewicz, B. Recent advances in on-line methods based on extraction for speciation analysis of chromium in environmental matrices. Crit. Rev. Anal. Chem. 2015, 17, 305-322. [CrossRef] [PubMed]

15. Diniz, K.M.; Teixeira Tarley, C.R. Specition analysis of chromium in water samples through sequential combination of dispersive magnetic solid phase extraction using mesoporous amino-functionalized $\mathrm{Fe}_{3} \mathrm{O}_{4}-\mathrm{SiO}_{2}$ nanoparticles and cloud point extraction. Microchem. J. 2015, 123, 185-195. [CrossRef]

16. Herrero-Latorre, C.; Barciela-García, J.; García-Martín, S.; Pena-Crecente, R.M. Graphene and carbon nanotubes as solid phase extraction sorbents for the speciation of chromium: A review. Anal. Chim. Acta 2018, 1002, 1-17. [CrossRef]

17. Mohammadkhani, S.; Gholami, M.R.; Aghaie, M. Thermodynamic study of $\mathrm{Cr}^{+3}$ ions removal by "MnO $2 / \mathrm{MWCNT}^{\prime}$ nanocomposite. Orient. J. Chem. 2015, 31, 1429-1436. [CrossRef]

18. Rezvani, M.; Asgharinezhad, A.A.; Ebrahimzadeh, H.; Shekari, N. A polyaniline-magnetite nanocomposite as an anion exchange sorbent for solid-phase extraction of chromium(VI) ions. Microchim. Acta 2014, 181, 1887-1895. [CrossRef] 
19. Karimi, M.A.; Shahin, R.; Mohammadi, S.Z.; Hatefi-Mehrjardi, A.; Hashemi, J.; Yarahmadi, J. Speciation analysis of Cr(III) and $\mathrm{Cr}(\mathrm{VI})$ after solid phase extraction using modified magnetite nanoparticles. J. Chin. Chem. Soc. 2013, 60, 1339-1346. [CrossRef]

20. Branger, C.; Meouche, W.; Margaillan, A. Recent advances on ion-imprinted polymers. React. Funct. Polym. 2013, 73, 859-875. [CrossRef]

21. El Ouardi, Y.; Giove, A.; Laatikainen, M.; Branger, C.; Laatikainen, K. Benefit of ion imprinting technique in solid-phase extraction of heavy metals, special focus on the last decade. J. Environ. Chem. Eng. 2021, 9, 106548. [CrossRef]

22. Zambrzycka-Szelewa, E.; Leśniewska, B.; Godlewska-Żyłkiewicz, B. Preparation and application of ion-imprinted polymer sorbents in separation process of trace metals. In MIP Synthesis, Characteristics and Analytical Application; Marć, M., Ed.; Comprehensive Analytical Chemistry; Elsevier: Amsterdam, The Netherlands, 2019; Volume 86, pp. 261-293. [CrossRef]

23. Birlik, E.; Ersoz, A.; Denizil, A.; Say, R. Cr(III)-imprinted polymeric beads: Sorption and preconcentration studies. J. Hazard. Mater. 2007, 140, 110-116. [CrossRef] [PubMed]

24. Leśniewska, B.; Jakubowska, I.; Zambrzycka, E.; Godlewska-Żyłkiewicz, B. A novel ion-imprinted polymeric sorbent for separation and determination of chromium(III) species in wastewater. Turk. J. Chem. 2016, 40, 933-943. [CrossRef]

25. Leśniewska, B.; Trzonkowska, L.; Zambrzycka, E.; Godlewska-Żyłkiewicz, B. Multi-commutation flow system with on-line solid phase extraction exploiting the ion-imprinted polymer and FAAS detection for chromium speciation analysis in sewage samples. Anal. Methods 2015, 7, 1517-1526. [CrossRef]

26. Leśniewska, B.; Jeglikowska, A.; Godlewska-Żyłkiewicz, B. Chromium speciation in wastewater and sewage by solid-phase extraction using a new diphenylcarbazone-incorporated resin. Water Air Soil Pollut. 2016, 227, 291. [CrossRef] [PubMed]

27. Leśniewska, B.; Godlewska-Żyłkiewicz, B.; Wilczewska, A.Z. Separation and preconcentration of trace amounts of Cr(III) ions on ion imprinted polymer for atomic absorption determinations in surface water and sewage samples. Microchem. J. 2012, 105, 88-93. [CrossRef]

28. Izzataddini, A.; Nurani, D.A.; Rahayu, D.U.C.; Abdullah, I. Preparation and characterization of an ion imprinted polymer for selective separation of $\mathrm{Cr}$ (III) ions from water. AIP Conf. Proc. 2020, 2242, 040036.

29. An, F.; Gao, B. Adsorption characteristics of $\mathrm{Cr}$ (III) ionic imprinting polyamine on silica gel surface. Desalination 2009, 249, 1390-1396. [CrossRef]

30. Zhang, N.; Suleiman, J.S.; He, M.; Hu, B. Chromium(III)-imprinted silica gel for speciation analysis of chromium in environmental water samples with ICP-MS detection. Talanta 2008, 75, 536-543. [CrossRef]

31. Liu, Y.; Meng, X.; Han, J.; Liu, Z.; Meng, M.; Wang, Y.; Chen, R.; Tian, S. Speciation, adsorption and determination of chromium(III) and chromium(VI) on a mesoporous surface imprinted polymer adsorbent by combining inductively coupled plasma atomic emission spectrometry and UV spectrophotometry. J. Sep. Sci. 2013, 36, 3949-3957. [CrossRef]

32. Cen, S.; Li, W.; He, R.; Tan, J.; Wang, H.; Wei, C.; Tang, Y. Preparation of an ion imprinted functionalized mesoporous silica for rapid and specific absorption Cr(III) ions in effluents. RSC Adv. 2017, 7, 37778-37786. [CrossRef]

33. Jamshidi, M.; Ghaedi, M.; Dashtian, K.; Hajati, S. New ion-imprinted polymer-functionalized mesoporous SBA-15 for selective separation and preconcentration of $\mathrm{Cr}$ (III) ions: Modeling and optimization. RSC Adv. 2015, 5, 105789-105799. [CrossRef]

34. Trzonkowska, L.; Leśniewska, B.; Godlewska-Żyłkiewicz, B. Studies on the effect of functional monomer and porogen on the properties of ion imprinted polymer based on $\mathrm{Cr}(\mathrm{III})-1,10$-phenanthroline complex designer for selective removal of $\mathrm{Cr}(\mathrm{III})$ ions. React. Funct. Polym. 2017, 117, 131-139. [CrossRef]

35. Gao, X. Cis-dichloridobis(1,10-phenanthroline)chromium(III) chloride. Acta Cryst. 2011, E67, m139. [CrossRef] [PubMed]

36. Hoet, P. Speciation of chromium in occupational exposure and clinical aspects. In Handbook of Elemental Speciation II: Species in the Environment, Food, Medicine and Occupational Health; Cornelis, R., Crews, H., Caruso, J., Heumann, K.G., Eds.; John Wiley and Sons, Ltd.: Chichester, UK, 2005; pp. 135-157.

37. Inczedy, J.; Lengyel, T.; Ure, A.M.; Gelencser, A.; Hulanicki, A. Compendium of Analytical Nomenclature, 3rd ed.; IUPAC, Blackwell Science: Oxford, UK, 1998.

38. Tiwari, S.; Sharma, N.; Saxena, R. On-line speciation of chromium using a modified chelating resin and determination in industrial water samples by flame atomic absorption spectrometry. New J. Chem. 2016, 40, 1412-1419. [CrossRef]

39. Saxena, R.; Sharma, N.; Tiwari, S. Chromium speciation using flow-injection preconcentration on xylenol orange functionalized Amberlite XAD-16 and determination in industrial water samples by flame atomic absorption spectrometry. Anal. Sci. 2015, 31, 1303-1308. [CrossRef] [PubMed]

40. Karak, T.; Bhagat, R.M. Trace elements in tea leaves, made tea and tea infusion: A review. Food Res. Int. 2010, 43, $2234-2252$. [CrossRef]

41. Hamilton, E.M.; Young, S.D.; Bailey, E.H.; Watts, M.J. Chromium speciation in foodstuffs: A review. Food Chem. 2011, 129, 1839-1843. [CrossRef]

42. Xiong, W.; Cheng, C.; Yang, Y. Determination of total chromium in tea samples by suspension dispersive solid phase extraction combined with silver nanoparticles and using flame atomic absorption spectrometry. Anal. Methods 2015, 7, 2093-2099. [CrossRef] 